\title{
Seasonal variation of haemoglobin Alc in a Portuguese adult population
}

Maria Teresa Rocha e Pinho Pereira', Domingos Lira', Conceição

Bacelar', José Carlos Oliveira ${ }^{2}$, André Couto de Carvalho'

\begin{abstract}
Objective: Haemoglobin A1c ( $\mathrm{Hb} \mathrm{A} 1 \mathrm{c}$ ) is routinely used for monitoring glycemic control in patients with diabetes. $\mathrm{Hb}$ A1c seasonal fluctuations can be directly related to different biological, geographical and cultural influences. Our purpose was to evaluate seasonal variation of $\mathrm{Hb} \mathrm{A1c}$ in a hospitalbased adult population over a period of 5 years. Materials and methods: We analyzed retrospectively monthly $\mathrm{Hb}$ A1c mean values (DCCT, \%) based on all the assays performed to adult patients at a tertiary care university Portuguese hospital between 2008-2012. Results: We obtained 62,384 $\mathrm{Hb}$ A1c valid measurements, with a peak level found in January-February (7.1\%), a trough in AugustOctober $(6.8 \%)$ and an average peak-to-trough amplitude value of $0.3 \%$. This trend was observed in both genders and age subgroups evaluated. Conclusions: There is a $\mathrm{Hb} \mathrm{A1c}$ circannual seasonal pattern with peak levels occurring in winter months in this Portuguese population. This finding should be recognized in daily clinical practice to warrant better clinical and epidemiological interpretation of Hb A1c values. Arch Endocrinol Metab. 2015;59(3):231-5
\end{abstract}

Keywords

Seasonal variation; haemoglobin A1c; blood glucose
1 Division of Endocrinology,

Diabetes and Metabolism, Hospital de Santo António - Centro

Hospitalar do Porto, Porto, Portugal ${ }^{2}$ Department of Clinical Pathology, Hospital de Santo António - Centro Hospitalar do Porto, Porto, Portugal

Correspondence to:

Maria Teresa Rocha e Pinho Pereira Division of Endocrinology,

Diabetes and Metabolism,

Hospital Santo António,

Largo Prof. Abel Salazar

4099-001 - Porto, Portugal

teresa.rocha.pereira@gmail.com

Received on June/8/2014 Accepted on Apr/16/2015

DOI: 10.1590/2359-3997000000043

\section{INTRODUCTION}

$\mathrm{T}$ he achievement of an adequate glycemic control is crucial in preventing chronic complications in diabetes (1). Haemoglobin Alc ( $\mathrm{Hb} \mathrm{Alc}$ ) is a marker of the average blood glucose levels in the past 90 days and is commonly used as a predictor of diabetic complications $(2,3)$.

Several human physiologic parameters are known to be influenced by seasonal cycles (4). Some, as blood pressure levels, heart rate, lipid profile, insulin and cortisol serum levels are also factors associated to the development of many diseases and cardiovascular events (5-9). Seasonal changes on type 1 diabetes incidence have also been reported in literature, with new onset cases diagnosed more commonly during winter months (10). Many influences have been linked to these occurrences such as increased viral infections incidence, amount of exercise taken, vitamin D serum concentrations, hormonal fluctuations as well as increased insulin sensitivity during summer $(10,11)$. This variation pattern seems to be associated with the geographic loca- tion, particulary when different latitudes and respective temperature variations between winter and summer are considered $(11,12)$. It has been suggested that seasonal fluctuations also occur in glycemic control in both type 1 and type 2 diabetic patients (13-17). There are several epidemiological reports coming from different geographic areas that exhibit clinical relevant $\mathrm{Hb} \mathrm{Alc} \mathrm{cir-}$ cannual fluctuations $(15,16,18,19)$. Most of them were performed in the northern hemisphere, with higher $\mathrm{Hb} \mathrm{Alc} \mathrm{levels} \mathrm{found} \mathrm{in} \mathrm{winter} \mathrm{colder} \mathrm{months} \mathrm{and} \mathrm{lo-}$ wer values during summer time. The exact mechanism through which different seasons would induce changes on $\mathrm{Hb} \mathrm{Alc} \mathrm{levels} \mathrm{is} \mathrm{not} \mathrm{fully} \mathrm{understood.} \mathrm{The} \mathrm{availa-}$ ble data suggest that there is a complex of potential environmental, biologic and cultural factors implicated (especially festive-food intake patterns, physical activity or even exposure to sunlight).

In Portugal, to the best of our knowledge, there are no published data concerning this issue. Our purpose was to evaluate $\mathrm{Hb} \mathrm{Alc}$ variation across different months for a five year-period (2008-2012) and to confirm the presence of any seasonal effect. 


\section{MATERIALS AND METHODS}

We retrieved data from the electronic medical records of Hospital Santo Antonio - Centro Hospitalar do Porto, a tertiary care university hospital center in the northern of Portugal (latitude $41^{\circ} 08^{\prime}$ North) from $1^{\text {st }}$ January 2008 to $31^{\text {st }}$ December 2012. Mean local temperature ranged during this time between an average minimum and maximum of $5.2^{\circ} \mathrm{C}$ and $25.7^{\circ} \mathrm{C}$ in January and August, respectively (20). The data collected were unidentified and included only age, sex, date of blood collection and $\mathrm{Hb} \mathrm{Alc}$ levels. In total, we collected $63,785 \mathrm{Hb}$ Alc measurements and retained 62,384 after excluding both extreme values $(<$ $3 \%$ and/or $>18 \%$ ) and patients younger than 18 yearsold. All $\mathrm{Hb} \mathrm{Alc}$ results are expressed in percentage (\%) using the National Glycohemoglobin Standardization Program/Diabetes Control and Complications Trial (NGSP/DCCT) certified method and were performed on ethylenediamine tetra-acetic acid (EDTA) blood specimens using cation-exchange high performance liquid chromatography (HPLC) Adams Alc HA8160, Diabetes Mode equipment (Arkray, Inc., Kyoto, Japan). This method did not change over the 5-year study period. The mean $\mathrm{Hb} \mathrm{Alc}$ and the $95 \%$ confidence interval $(\mathrm{CI})$ were calculated for each month as well as the prevalence of $\mathrm{Hb} \mathrm{Alc} \mathrm{values} \mathrm{above} 6.5$ and $9.0 \%$. The subjects were further classified into gender and age subgroups ( $<35-\mathrm{yr}, 35$ to $64-\mathrm{yr}$ and $\geq 65-\mathrm{yr}$ ). To determine whether there were differences between the monthly means, Kruskal-Wallis with post hoc analysis using Dunn's test were used. Comparisons between distinct $\mathrm{Hb} \mathrm{Alc}$ prevalence cut-points were performed by using $\mathrm{X}^{2}$ test. Statistical analysis was performed using GraphPad Prism version 6.0 (GraphPad Software, Inc., La Jolla, California, USA) and differences were considered to be statistically significant at $\mathrm{p}<0.05$ level.

\section{RESULTS}

Over the period between January 2008 and December 2012 we analyzed a total of $62,384 \mathrm{Hb}$ Alc records corresponding, in average to 1,039 per month. Gender distribution was almost even (49\% women). Patient's age ranged from 19 to 104 years-old with the following dispersion: < 35-yr, 7.5\% ( $\mathrm{n}=4,679)$; 35-64-yr, 51.1\% $(\mathrm{n}=31,878)$; and $\geq 65-\mathrm{yr}, 41.4 \%(\mathrm{n}=25,827)$. The overall mean $\mathrm{Hb}$ Alc was $6.9 \pm 1.7 \%$ (95\% CI, 6.9-7.0\%).

Evaluating month-dependent data we have found a consistent $\mathrm{Hb}$ Alc cyclical fluctuation (repeated over the five years) with higher average values observed in January and February (peak of $7.1 \pm 1.9 \%$ in February) and gradually decline after spring-summer months until August to October (nadir of $6.8 \pm 1.7 \%$ in September) (Table 1$)$. A significant growing trend $(\mathrm{p}<0.0001)$ was detected from October till February with a mean peakto-trough variation between February and September of about $0.3 \%$ (Figure 1). No differences were found between consecutive months. The same seasonal trend

Table 1. Monthly mean Hb A1c value in a Portuguese hospital-based adult population from January 2008 to December $2012(n=62,384)$

\begin{tabular}{|c|c|c|c|c|c|c|c|c|}
\hline \multirow{3}{*}{ Month } & \multicolumn{6}{|c|}{ Hb A1c (\%, mean \pm standard deviation) } & \multirow{3}{*}{$\begin{array}{c}\text { Mean Hb A1c } \\
>6.5 \%(\%)\end{array}$} & \multirow{3}{*}{$\begin{array}{c}\text { Mean Hb A1c } \\
>\mathbf{9} \%(\%)\end{array}$} \\
\hline & \multirow{2}{*}{ Total } & \multicolumn{2}{|c|}{ Gender } & \multicolumn{3}{|c|}{ Age Group } & & \\
\hline & & Male & Female & $<35-y r$ & $35-64-y r$ & $\geq 65-y r$ & & \\
\hline January & $7.1 \pm 1.9^{a}$ & $7.0 \pm 1.8^{\mathrm{a}}$ & $7.2 \pm 2.0^{a, b}$ & $7.1 \pm 2.1^{c}$ & $7.2 \pm 2.0^{a, b}$ & $7.0 \pm 1.7^{c}$ & $51.6^{a}$ & $15.2^{\mathrm{a}}$ \\
\hline February & $7.1 \pm 1.9^{\mathrm{a}}$ & $7.1 \pm 1.9^{a, b}$ & $7.1 \pm 1.9^{\mathrm{a}, \mathrm{b}}$ & $7.1 \pm 2.2^{c}$ & $7.2 \pm 2.0^{\mathrm{a}, \mathrm{b}}$ & $7.0 \pm 1.7^{\mathrm{a}}$ & $53.0^{\mathrm{a}}$ & $14.7^{\mathrm{a}}$ \\
\hline March & $7.0 \pm 1.8^{\mathrm{a}}$ & $7.0 \pm 1.8^{a, b}$ & $7.1 \pm 1.9^{b}$ & $7.0 \pm 2.2$ & $7.2 \pm 1.9^{a, b}$ & $6.9 \pm 1.6^{\mathrm{a}}$ & $51.3^{\mathrm{a}}$ & $13.1^{b}$ \\
\hline April & $7.0 \pm 1.8^{\mathrm{a}}$ & $6.9 \pm 1.8$ & $7.1 \pm 1.9^{a, b}$ & $6.9 \pm 2.2$ & $7.0 \pm 1.9$ & $7.0 \pm 1.6^{\mathrm{a}}$ & $50.1^{b}$ & $13.6^{\mathrm{a}}$ \\
\hline May & $6.9 \pm 1.8$ & $6.9 \pm 1.7$ & $7.0 \pm 1.8$ & $6.9 \pm 2.2$ & $7.0 \pm 1.9$ & $6.8 \pm 1.5$ & 48.1 & 11.5 \\
\hline June & $6.9 \pm 1.7$ & $6.9 \pm 1.7$ & $6.9 \pm 1.8$ & $6.8 \pm 2.0$ & $7.0 \pm 1.8$ & $6.9 \pm 1.5$ & 48.7 & 11.2 \\
\hline July & $6.9 \pm 1.7$ & $6.8 \pm 1.7$ & $6.9 \pm 1.8$ & $6.8 \pm 2.0$ & $7.0 \pm 1.9$ & $6.8 \pm 1.5$ & 47.2 & 11.0 \\
\hline August & $6.8 \pm 1.7$ & $6.8 \pm 1.7$ & $6.9 \pm 1.7$ & $6.6 \pm 2.1$ & $6.9 \pm 1.8$ & $6.7 \pm 1.5$ & 45.2 & 10.3 \\
\hline September & $6.8 \pm 1.7$ & $6.8 \pm 1.6$ & $6.9 \pm 1.8$ & $6.6 \pm 2.1$ & $6.9 \pm 1.8$ & $6.8 \pm 1.5$ & 45.4 & 11.0 \\
\hline October & $6.8 \pm 1.7$ & $6.8 \pm 1.6$ & $6.9 \pm 1.8$ & $6.7 \pm 2.1$ & $6.9 \pm 1.8$ & $6.8 \pm 1.5$ & 46.3 & 11.2 \\
\hline November & $6.9 \pm 1.7$ & $6.8 \pm 1.6$ & $7.0 \pm 1.8$ & $6.7 \pm 2.1$ & $6.9 \pm 1.9$ & $6.8 \pm 1.5$ & 45.7 & 11.4 \\
\hline December & $6.9 \pm 1.8$ & $6.9 \pm 1.7$ & $7.0 \pm 1.9$ & $7.2 \pm 2.3^{c}$ & $7.0 \pm 1.9$ & $6.8 \pm 1.5$ & 47.6 & $12.7^{c}$ \\
\hline
\end{tabular}

a $p<0.001$ vs. September and/or October; ${ }^{b} p<0.01$ vs. October and/or November; ${ }^{c} p<0.05$ vs. September and/or October. 


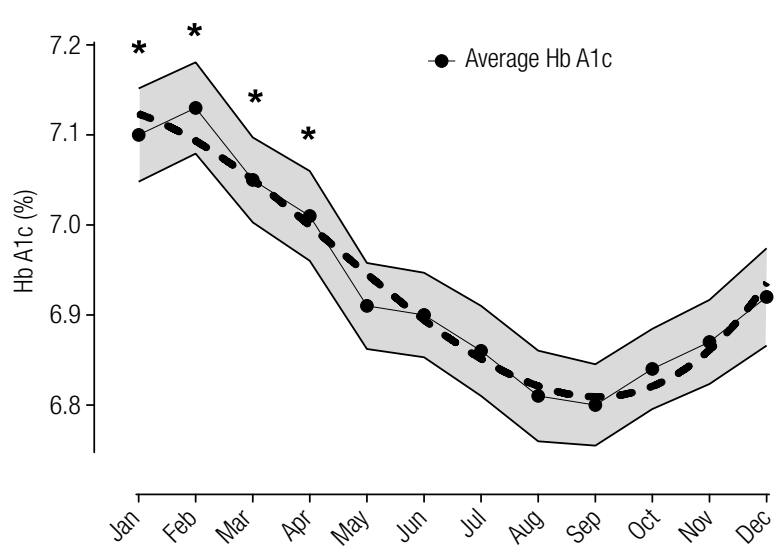

Figure 1. Time series plot of average $\mathrm{Hb} A 1 \mathrm{C}(\%)$ obtained from data between January-2008 and December-2012. Gray interval represent $95 \%$ confidence value for each monthly mean $\mathrm{Hb}$ A1c. Dashed line describe a polynomial best-fit curve for mean $\mathrm{Hb} \mathrm{A1c}\left(\mathrm{R}^{2}=0.94\right)$. ${ }^{*} \mathrm{p}<$ 0.001 vs. August, September and October.

was found when evaluating prevalence fluctuations of $\mathrm{Hb}$ Alc values greater than 6.5 or $9.0 \%$, with higher dimension in January-February and lower proportion between August-September $(\mathrm{p}<0.001)$ (Table 1). Time series analysis with age and sex subgroups shared this same seasonal trend with higher $\mathrm{Hb}$ Alc levels in January till April when comparing with its nadir in September $(\mathrm{p}<0.05)$ (Figure 2).

\section{DISCUSSION}

In our temperate northern Portuguese climate $\mathrm{Hb} \mathrm{Alc}$ levels among an hospital-based population present a circannual cyclical pattern with peaks in mid-summer and troughs in late-summer. Monthly averages $\mathrm{Hb}$ Alc were significantly higher during the cooler winter months of January-February and lower immediately af- ter the warmer summer months, reflecting plasma glucose excursions throughout the previous 2-3 months, with a mean absolute amplitude between winter-summer of $0.3 \%$.

Our data are consistent with previous reports assessing seasonal variation of $\mathrm{Hb} \mathrm{Alc}$. Most of these works were performed in western countries from the northern hemisphere, where similar $\mathrm{Hb} \mathrm{Alc}$ circannual fluctuation patterns, with higher levels during cooler autumn-winter months and lower levels during warmer summer-spring time, were described in both children and adult individuals with or without diabetes $(14,16,18,21-23)$. In the United States, Tseng and cols. noted that $\mathrm{Hb} \mathrm{Alc}$ peak and trough was found in January-February and September-October months, respectively, with a mean amplitude of $0.22 \%$ (16). Furthermore, they documented that this seasonal variation was accentuated at higher latitudes areas where greater temperature differences between winter and summer also occur. Likewise in adult diabetic patients from Sweden, Asplund reported its highest values in January $(7.61 \%)$ and its lowest values in July $(7.23 \%)$, with an amplitude of $0.38 \%$ (14). More recently, Kim and cols. analyzed $\mathrm{Hb} \mathrm{Alc}$ seasonal variations in a large scale population of Korean patients with type 2 diabetes mellitus and also found a peak in February-March (late winter-early spring) and a trough in September-October (early autumn) with a negative correlation with average daily temperature and an amplitude range $0.16 \%$ to $0.25 \%(24)$. Likewise, a neighboring Spanish paper of Escribano-Serrano and cols. has documented higher mean $\mathrm{Hb}$ Alc values in January (7.01\%) and minimal values in October (6.74\%), with a significant magnitude of $0.27 \%(25)$. In contrast, another study also under-

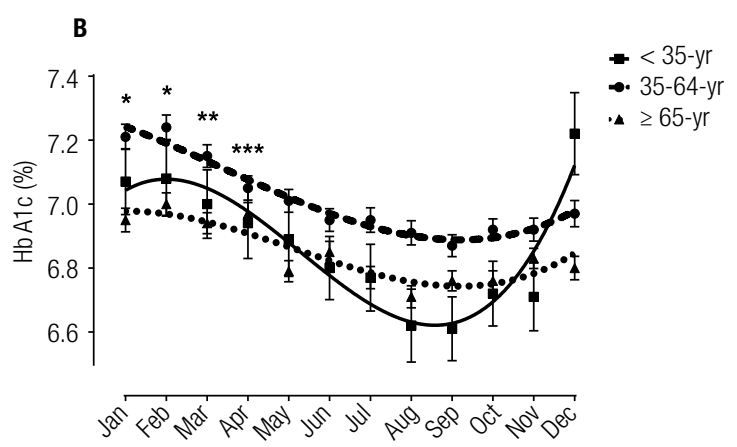

Figure 2. Time series plot of $\mathrm{Hb} \mathrm{A} 1 \mathrm{C}$ data (mean \pm standard error of the mean) between January-2008 and December-2012 based on gender and age sub-groups. (A) Mean Hb A1c level in all subjects (global) and grouped by gender (female/male). Solid line: best fit curve for all subjects; dashed line: for female; and dotted line: for male population. (B) Mean $\mathrm{Hb}$ A1c level presented by age group (<35-yr, 35 to 64 -yr and $\geq 65$-yr). Solid line: best fit curve for subjects less than 35-yr old; dashed line: for those between 35 and 64-yr; and dotted line: for those older than 65-yr. * $p<0.05$ vs. September (for both genders and all age groups); ${ }^{* \star} p<0.05$ vs. September (only for 35-64-yr and $\geq 65$-yr group); ${ }^{* \star \star} p<0.05$ vs. September (only for $\geq 65$-yr group). 
taken in the southern Spain, the authors found a slight fluctuation of $\mathrm{Hb}$ Alc levels (highest value in February and the lowest in July, $7.3 \%$ and $7.1 \%$, respectively), but with a small range of inter-monthly variation and without any significant seasonal effect (26). We speculate that this discrepancy observed between these two regions with similar latitude and average temperatures may be due to some differences found in their methodological approach and population size. Additionally, the gender and age subgroup analysis that was carried out by us was also consistent with other reports. Sakura and cols., in Japan, have showed a clear sinusoidal seasonal pattern of $\mathrm{Hb} \mathrm{Alc} \mathrm{levels} \mathrm{fluctuation} \mathrm{(peak} \mathrm{in}$ March and trough in August) with female and young subjects presenting a significantly greater amplitude of $\mathrm{Hb} \mathrm{Alc} \mathrm{variation} \mathrm{than} \mathrm{males} \mathrm{and} \mathrm{elderly} \mathrm{patients} \mathrm{(27).}$ Our results shared some this observed tendency, with a higher $\mathrm{Hb} \mathrm{Alc}$ peak-to-trough amplitude $(\sim 0.5 \%)$ in the youngest age subgroup ( $<35$ yr-old).

Similar circannual patterns were also reported for other metabolic features and hormones, suggesting that these variations may result from a complex physiological response to some seasonal environmental elements $(21,23)$. Cold and other climate conditions have been explored as potential enhancing factors underlying to these cyclical physiological variations. Several authors suggested that the plasma glucose increase observed during winter months may result from an innate physiological homeostatic response that includes a normal thermoregulatory body strategy against cold (23). Available evidence concerning this issue point to a direct effect of low ambient temperature exposure on metabolic axis through consequent rise in counter regulatory hormones concentrations during cold stress $(7,28)$. This rise of blood glucose levels could be associated with an increased need of heat production that could be achieved by increasing serum morning cortisol, epinephrine, thyroid hormones, glucagon and growth hormone concentrations (29). Intrinsic season-related effects and changes on carbohydrate metabolism, particularly on gluconeogenesis, were also described in cold-adapted rats exposed to low temperatures (30). Rises in serum cortisol levels and increase tissue sensitivity to glucocorticoids is a recognized effect during cold months that could account for some of the body fat gain and consequent insulin resistance also observed over winter (5,31). Likewise, several human seasonal nutritional characteristics, such as the excessive caloric intake during winter festivities, and cultural as- pects, such as simultaneous decreased physical activity, are known to be associated to an increase of adiposity with secondary insulin resistance establishment during this period (15). Some previous studies have showed that this seasonal variation in physical activity is coincident with other circannual fluctuations in physiological markers such as lipid profile, blood pressure, bone mineral density and psycho-affective disorders changes (32). Other theories have been proposed to explain this phenomenon which included greater frequency of minor viral infections, changes in host susceptibility to infection and seasonal occurrence of some psychological alterations (11). In an attempt to control climate influence on glycemic control Hawkins examined the $\mathrm{Hb} \mathrm{Alc}$ circannual variation in a tropical country with no significant temperature variation (33). Their results failed to reveal any seasonal pattern and reinforced the deleterious effect of dietary indiscretion during festivities in glycemic control. Recently, other authors pointed out for the inverse association between serum 25- $(\mathrm{OH})$-vitamin D and glycemic metabolism, suggesting that this sun-dependent hormone might have some direct intervention on glucose homeostasis and therefore be also implicated in the $\mathrm{Hb}$ Alc circannual fluctuation $(34,35)$.

Our study has some limitations. First, it is based on a retrospective analysis from data extracted through a patient computer database. As such, we cannot consider for evaluation other potentially confounding factors than the ones available and presented here (age and gender). Second, the studied population may have some age and metabolic characteristics that does not allow us to extrapolate these results to other different populations of healthy individuals or adults with glycemic disorders. On the other hand, we highlight the large number (over 60,000) of $\mathrm{Hb}$ Alc evaluations evaluated that came from a single hospital center with a stable patient population and analytical methodology practice.

In conclusion, this study has described a circannual pattern of $\mathrm{Hb} \mathrm{Alc}$ levels in adult subjects of northern Portugal with a peak in January-February, nadir in August-October and a mean amplitude of $0.3 \%$. Health providers and researchers must be aware of this $\mathrm{Hb} \mathrm{Alc}$ seasonal variation and consider adjusting epidemiological and clinical decisions to the local season, climate and calendar festivities circumstances. Special concern should be present when using $\mathrm{Hb} \mathrm{Alc}$ levels to diagnose diabetes mellitus in temperate countries where the presence of a significant peak-to-trough amplitude 
could easily misdiagnose patients over distinct months. This study also emphasizes the need for more efficient methods to overcome culture and dietary barriers present during winter holidays.

Disclosure: no potential conflict of interest relevant to this article was reported.

\section{REFERENCES}

1. McGill M, Felton AM; Global Partnership for Effective Diabetes Management. New global recommendations: a multidisciplinary approach to improving outcomes in diabetes. Prim Care Diabetes. 2007;1(1):49-55.

2. UK Prospective Diabetes Study. IV. Characteristics of newly presenting type 2 diabetic patients: male preponderance and obesity at different ages. Multi-center Study. Diabet Med. 1988;5(2):154-9.

3. The effect of intensive treatment of diabetes on the development and progression of long-term complications in insulin-dependent diabetes mellitus. The Diabetes Control and Complications Trial Research Group. N Engl J Med. 1993;329(14):977-86.

4. Mavri A, Guzic-Salobir B, Salobir-Pajnic B, Stare J, Stegnar M. Seasonal variation of some metabolic and haemostatic risk factors in subjects with and without coronary artery disease. Blood Coagul Fibrinolysis. 2001;12(5):359-65.

5. Walker BR, Best R, Noon JP, Watt GC, Webb DJ. Seasonal variation in glucocorticoid activity in healthy men. J Clin Endocrinol Metab. 1997;82(12):4015-9.

6. DonahooWT, Jensen DR, ShepardTY, Eckel RH. Seasonal variation in lipoprotein lipase and plasma lipids in physically active, normal weight humans. J Clin Endocrinol Metab. 2000;85(9):3065-8.

7. Kristal-Boneh E, Froom P, Harari G, Malik M, Ribak J. Summerwinter differences in $24 \mathrm{~h}$ variability of heart rate. $\mathrm{J}$ Cardiovasc Risk. 2000;7(2):141-6.

8. Urbansky HF. Role of circadian neuroendocrine rhythms in the control of behavior and physiology. Neuroendocrinology. 2011;93(4):211-22.

9. Spencer FA, Goldberg RJ, Becker RC, Gore JM. Seasonal distribution of acute myocardial infarction in the second National Registry of Myocardial Infarction. J Am Coll Cardiol. 1998;31(6):1226-33.

10. Cantorna MT. Vitamin $D$ and autoimmunity: is vitamin $D$ status an environmental factor affecting autoimmune disease prevalence? Proc Soc Exp Biol Med. 2000;223(3):230-3.

11. Moltchanova EV, Schreier N, Lammi N, Karvonen M. Seasonal variation of diagnosis of type 1 diabetes mellitus in children worldwide. Diabet Med. 2009;26(7):673-8.

12. Mortensen HB, Vestermark S, Kastrup KW. Metabolic control in children with insulin dependent diabetes mellitus assessed by haemoglobin A1c. Acta Paediatr Scand. 1982;71(2):217-22.

13. Maguire GA, Edwards OM. Seasonal variation in glycated haemoglobin in diabetics. Ann Clin Biochem. 2001;38(1):59-60.

14. Asplund J. Seasonal variation of $\mathrm{HbA} 1 \mathrm{C}$ in adult diabetic patients. Diabetes Care. 1997;20(2):234.

15. Sohmiya M, Kanazawa I, Kato Y. Seasonal changes in body composition and blood $\mathrm{HbA} 1 \mathrm{c}$ levels without weight change in male patients with type 2 diabetes treated with insulin. Diabetes Care. 2004;27(5):1238-9.

16. Tseng $C L$, Brimacombe $M$, Xie $M$, Rajan $M$, Wang $H$, Kolassa J, et al. Seasonal patterns in monthly hemoglobin A1c values. Am J Epidemiol. 2005;161(6):565-74.
17. Liang WW. Seasonal changes in preprandial glucose, A1C, and blood pressure in diabetic patients. Diabetes Care. 2007;30(10):2501-2.

18. Gikas A, Sotiropoulos A, Pastromas V, Papazafiropoulou A, Apostolou O, Pappas S. Seasonal variation in fasting glucose and $\mathrm{HbA} 1 \mathrm{c}$ in patients with type 2 diabetes. Prim Care Diabetes. 2009;3(2):111-4.

19. Higgins T, Saw S, Sikaris K, Wiley CL, Cembrowski GC, Lyon AW, et al. Seasonal variation in hemoglobin A1c: Is it the same in both hemispheres? J Diabetes Sci Technol. 2009;3(4):668-71.

20. The Portuguese Sea and Atmosphere Institute (a government organization). (2015). Available from: http://www.ipma.pt. Accessed on: June 1, 2014.

21. Garde AH, Hansen AM, Skovgaard LT, Christensen JM. Seasonal and biological variation of blood concentrations of total cholesterol, dehydroepiandrosterone sulfate, haemoglobin $A(1 c), \lg A$, prolactin, and free testosterone in healthy women. Clin Chem. 2000;46(4):551-9.

22. Jarrett RJ, Murrells TJ, Shipley MJ, Hall T. Screening blood glucose values: effects of season and time of day. Diabetologia. 1984;27(6):574-7.

23. MacDonald MJ, Liston L, Carlson I. Seasonality in glycosylated haemoglobin in normal subjects. Does seasonal incidence in insulin-dependent diabetes suggest specific etiology? Diabetes. 1987;36(3):265-8.

24. Kim Y, Park S, Yi W, Yu KS, Kim TH, Oh TJ, et al. Seasonal variation in hemoglobin A1c in Korean patients with type 2 diabetes mellitus. J Korean Med Sci. 2014;29(4):550-5.

25. Escribano-Serrano J, García-Domínguez L, Díaz-Pintado-García MT, Salaya-Algarin G. Seasonal variation in glycated haemoglobin A1c (HbA(1c)) determinations. Aten Primaria. 2012;44(2):121-2.

26. Gomez-Huelgas R, Santamaria-Fernandez S, Guijarro-Merino R, Navajas-Luque F, Tinahones FJ, San Roman-Teran CM, et al. Seasonal variability of glycated hemoglobin in a diabetic population from southern Europe. J Diabetes Complications. 2013;27:618-20.

27. Sakura $H$, Tanaka $Y$, Iwamoto $Y$. Seasonal fluctuations of glycated hemoglobin levels in Japanese diabetic patients. Diabetes Res Clin Pract. 2010;88:65-70.

28. Woodhouse PR, Khaw KT, Plummer M. Seasonal variation of blood pressure and its relationship to ambient temperature in an elderly population. J Hypertens. 1993;11(11):1267-74.

29. Bittel JH. Heat debt as an index for cold adaptation in men. J Appl Physiol. 1987;62(4):1627-34.

30. Kuroshima A, Kurahashi M, Doi K, Ono T, Fukita I. Effect of cold adaptation and high-fat diet on cold resistance and metabolic responses to acute cold exposure in rats. Jpn J Physiol. 1974;24(3):277-92.

31. Hansen AM, Garde AH, Skovgaard LT, Christensen JM. Seasonal and biological variation of urinary epinephrine, norepinephrine, and cortisol in healthy women. Clin Chim Acta. 2001;309(1):25-35.

32. Matthews CE, Freedson PS, Hebert JR, Stanek EJ 3rd, Merriam $\mathrm{PA}$, Rosal MC, et al. Seasonal variation in household, occupational, and leisure time physical activity: longitudinal analyses from the seasonal variation of blood cholesterol study. Am J Epidemiol. 2001;153(2):172-83.

33. Hawkins RC. Circannual variation in glycohemoglobin in Singapore. Clin Chim Acta. 2010;411(1-2):18-21.

34. Forouhi NG, Luan J, Cooper A, Boucher BJ, Wareham NJ. Baseline serum 25 -hydroxy vitamin $D$ is predictive of future glycemic status and insulin resistance: the Medical Research Council Ely Prospective Study. 1990-2000. Diabetes. 2008;57(10):2619-25.

35. Zhao G, Ford ES, Li C. Associations of serum concentrations of 25-hydroxyvitamin $D$ and parathyroid hormone with surrogate markers of insulin resistance among U.S. Adults without physician-diagnosed diabetes: NHANES, 2003-2006. Diabetes Care. 2010;33(2):344-7. 